I am not, unfortunately, sufficiently well versed in natural philosophy to enter into the interesting facts detailed by Dr. Walsh relative to electricity. If, however, those of its passing from west to east, and of water being its best conductor, are confirmed, I should be led to suppose that the east coast of China would not be much under its influence, since no part of the Asiatic continent except its eastern and southern boundaries are in contact with the sea.

A very little observation is necessary to remark the differences in the complexion which exist amongst the natives of the different provinces, as we go from south to north.

Exposure to the sun has, undoubtedly, a great effect in rendering those whose occupations oblige them to submit to its influence much darker than their more opulent brethren; but it is as undoubtedly the case, that the use of opium and chalk, both of which are used in large quantities, are productive of the "waxy complexions" which Dr. Walsh mentions. (The latter, it may be observed, is used by the women to produce an artificial whiteness of the exposed parts of their bodies.)

Whiskers are by no means so uncommon as are generally supposed, but when they appear they are carefully plucked out; and if I can judge of the virility of the Chinese by the prodigious numbers of children (not taking into account the numbers of females which are doomed to death) which every even insignificant village produces, I cannot believe that the east coast of China suffers much from the effects of negative electricity.-I am, Sir, your obedient servant,

Wilson Ramsay, Surgeon 79th Regiment Militia.

Longford, Ireland, July, 1846.

\section{BREACHES OF CONFIDENCE AND MEDICAL FEES AT ASSURANCE OFFICES.}

\section{To the Editor of THe LANCET.}

Srn,-I have read with much pleasure two letters in your spirited journal (June 27 th, pages 709,710 ) on this subject, in answer to the call of Mr. Stookes (May 16th, page 558) " to publish the breaches of confidence, or furnish me with proofs that my assertion is no slander." If medical men were to respond to these, in all the "cases they have met with," I am inclined to believe they would tend to lessen the arrogant assurance of these would-be "strictly confidential directors" and if they did, what they in justice to themselves should do, they would manfully refuse to reply in toto, and not be, as many are, haunted by the bugbear-fear, or sacrifice a public principle to private interest. The cause is in our own hands, and if we were all to refuse, what could the offices do? It is a maxim.-If you want a thing done well, do it yourself. In the meantime, until a national, or all the local associations settle the dispute, I cannot too much impress upon my medical brethren the means that have served me to get my patients insured, as well as to rid myself of the responsibility contained in my letter, (The Lascet, June 13th, page 664,) and in proof, I herewith forward the name of an office in London, where the first printed rule states, "Two referees will also be required, one of whom is to be the usual medical attendant of the party proposed for assurance, from whom the society may receive, free of charge, the requisite information relative to the state of health," \&c. \&c. I shall be much enlightened if you or any of your readers can show by what authority the directors have the licence to appoint the whole body of the profession their servants, "free of charge." I admit their right to appoint and call for the time and services of a cab or waterman, but certainly not those of a whole profession, or even mine. Should you deem this worthy a niche in your journal, it may, perhaps, lead some of your readers to embrace the same opinions as, Sir, your obliged, humble servant,

Lucas-place, Commercial.road, June, 1846.

William Self.

\section{MEDICAL FEES AT ASSURANCE OFFICES.}

\section{To the Editor of THe Larcet.}

SIr,--The various methods which have been suggested and adopted by several correspondents, to enforce the payment of fees for answering the medical questions required by Life Assurance Societies, have not yet been attended with the success they deserve; the evils consequent on a refusal to answer, or otherwise if not answered to the satisfaction of the party, are well illustrated by Mr. Self and Mr. Camden. I shall therefore at once ask how the general practitioner can expect payment when we see physicians and surgeons of pre- sumed talent, professional reputation, and lucrative practice, lending themselves to a system which they may crush at once. Take, for example, the advertising sheet of a late number of THE LANCET; you will see advertised there a Life Assurance Company with two physicians and two surgeons as medical officers. Now it may fairly be asked,-Are these men paid by the office for their medical services? If so, why not explain the necessity, the justice, of remunerating medical information wherever obtained? (This example will suffice for every office where medical men are not remunerated; I am aware there are exceptions.) It is to these men atteution must be directed; for so long as they can be found upholding such a system, their humbler brethren must quietly submit.I am, Sir, your obedient servant,

Bath, June, 1846 .

E. Нихт.

\section{TREATMENT IN RETAINED PLACENTA.}

\section{To the Editor of Tre Latcex.}

Sir,-Would you or some of your numerous medical readers be kind enough to say what would be the proper conrse of practice to pursue in the following case. By far the larger portion of the midwifery practice of my neighbourhood falls to the lot of the old women.

A. B _ a fine, healthy young woman, was attended in her confinement by one of these old women, but owing, I suppose, to some adhesion, she could not extract the placenta, and unfortunately, not liking to acknowledge her incapacity left it in the uterus without applying for any assistance. I suppose, she told the young woman, and her friends, if she had any, (the child being illegitimate,) that all would be right and, as far as I can learn, the young woman suffered no in convenience, getting up and following her usual employment on the third day. She continued to do so until the sixth day, when some of her friends or neighbours began to grow a little uneasy, and sent for a medical practitioner, who forcibly introduced his hand into the contracted uterus, and extracted the placenta. The woman died in less than an hour afterwards, never recovering from the shock; for, as far as I can learn, there was no hæmorrhage, nor had she previously complained of any unusual pain.

Although I have repeatedly been called in after the midwives to extract the placenta, yet I have never met with a similar case of prolonged retention. But as such a circum. stance might happen any day, I feel desirous to have the opinion of some well-known accoucheur for such proceedings as I ought to be led to pursue. I find no directions given for the management of such cases in any of the works of midwifery in my possession, nor do I recollect the gentleman whose course of lectures on midwifery I attended ever mentioning such an occurrence as likely to happen. Ramsbotham mentions a case of retention which he saw in consultation on the sixth day, but in which no part of the placenta passed afterwards, except a piece of the size of a walnut. The case, which was left to Nature, ultimately did well.

L-m, June, 1946 . I am, Sir, your obedient servant, A Five Years' Stbscriber.

\section{THE QUACKS AND THEIR ABETTORS.}

\section{To the Editor of The Laxcert.}

Sir,- I trust that the readers of your journal are not confined to members of the medical profession. Were Tup Larcer to be seen as an hebdomadal adjunct to the breakfast-table of as large a number of the laity as the Times is, quackery would ere long receive its deathblow. Were some of our leading journals to devote one editorial article each week, exposing quackery in all its hydra-forms, the wished-for object would be attained, and at any rate a partial, if not an entire, suppression of this monster evil would be the consequence. But, Sir, instead of endeavour. ing to suppress, the journals of the day seem to uphold, or a least to countenance the system; and, strange to say, a gentieman holding the degree of M.D., and in practice as a surgeon at Tenby, is to be found as a public journalist admitting into the columns of his weekly paper advertisements of the direst quacks that ever belched forth their "lying wonders" to as easily-gulled public. The Tenby and Pembrokeshire Chronic came into existence about the latter end of last year, unde the editorship of Dr. Falconer, of Tenby. I happence to meet with a late number of this "Chronicle," when my at tion was arrested by an advertisement of "Professor IIo. loway," occupying half a column of its first page, ani 